\title{
Production of Alkaline Keratinolytic Protease by Bacillus sp. B13 from Feather Waste
}

\author{
Shilpa Ashok Jani ${ }^{1}$, Sumaiya Malek ${ }^{2}$, Anvi Patel ${ }^{3}$, Krupa Pathak ${ }^{2}$ and Kinjal Baria ${ }^{2}$ \\ ${ }^{1}$ Department of Microbiology, J and J College of Science, Nadiad, \\ Gujarat University, Gujarat, India \\ ${ }^{2}$ Department of Microbiology, Gujarat Science College, Ellisbridge, \\ Ahmedabad, Gujarat, India \\ ${ }^{3}$ Shri P.M. Patel Institute of P.G. studies and research in science, Anand, Gujarat, India \\ *Corresponding author
}

Keywords

Keratinolytic, Bacillus spp, Keratinolytic alkaline protease, Feather degradation

Article Info

Accepted: 17 April 2017 Available Online: 10 May 2017

\begin{abstract}
Alkaline keratinolytic protease producing Bacillus species was screened out from soil sample and characterized by studying morphological, cultural and biochemical properties. It was identified by using Burgey's manual of determinative bacteriology, identification flow charts as Bacillus alcalophilus. The isolate was employed for the production of alkaline protease by using production medium consisting of glucose and casein as carbon and nitrogen sources at $\mathrm{pH} 8.5$ (Rao and Narasu, 2007). The isolate was also checked for its protease production by using feathers as sole source of carbon and nitrogen and produced significant amount of alkaline keratinolytic protease from feathers. The production was optimized for different criteria like, temperature, $\mathrm{pH}$ of production medium, substrate concentration (feather), incubation period of production, inoculums size. The alkaline protease produced from feather waste was also checked for it's detergent compatibility and washing performance. It was found most compatible with detergent Wheel retaining $99.46 \%$ activity and with remarkable washing performance hence the enzyme can be used as detergent additive.
\end{abstract}

\section{Introduction}

Keratin-containing materials are insoluble and resistant to degradation by the common proteolytic enzymes. Keratinous wastes represent a source of valuable proteins and amino acids. Keratinolytic enzymes have potential roles in biotechnological processes involving keratin containing wastes from poultry and leather industries. Keratinolytic proteases have different application where keratins should be hydrolysed such as the leather and detergent industries, textiles waste bioconversion, medicine, cosmetics and many more novel outstanding applications. Several different strains of Bacillus, including $B$. pumilus, $B$. lichenifirmus, $B$. subtillis, $B$. halodurans or B. pseudofirmus are described to possess the ability of keratin biodegradation. Bacillus spp are known for production of wide variety of hydrolytic enzymes. So in this study we concentrated our study for isolating and characterizing one such Bacillus which degrades feather waste and produces alkaline protease from a cheaper raw material. 


\section{Materials and Methods}

\section{Alkaline protease producing microorganisms: source and screening}

Various samples of soil and water were collected from different regions of Delhousie of Himachal Pradesh, Manikarnam near Manali (HP), J and J college of Science, Nadiad, Gujarat, samples were aseptically collected from top soil surface.

One gram of soil sample was diluted in $10 \mathrm{ml}$ of sterile distilled water to make the sample and $1 \mathrm{ml}$ of water sample of each site were serially diluted using sterile distilled water, stirred thoroughly and $100 \mu \mathrm{l}$ aliquots were spread on skim milk agar medium of $\mathrm{pH}: 8.5$ and incubated at $37^{\circ} \mathrm{C}$ for $2-3$ days to allow the colonies to grow. The well isolated colonies were marked and colony characters and morphological characters were noted at the interval of $24 \mathrm{~h}$, diameter of zone of clearance of casein was also measured which provided a measure of their Proteolytic activity.

Measure of proteolytic activity on solid media

Fresh culture isolates producing zone of casein hydrolysis were taken and small drop was put in the middle of skim milk agar plate and incubated at $37^{\circ} \mathrm{C}$ for 5-6 days and at interval of $24 \mathrm{~h}$., zone of casein hydrolysis and diameter of growth were measured and relative enzyme activity (REA) was calculated (Jain et al., 2009).

(REA =Diameter of zone of casein hydrolysis/ Diameter of colony in $\mathrm{mm}$.)

Based on REA, organisms were categorized into three groups showing excellent $(\mathrm{REA}>5)$, good (REA $>2.0$ to, 5.0) and poor $(\mathrm{REA}<2)$ producer of protease.
Study of cultural, morphological and biochemical characteristics

The isolates showing zone of casein hydrolysis on milk agar plates, were studied for their colony characteristics, morphological and biochemical characteristics. Their morphological characteristics were studied by performing Gram's staining (Bergey et al., 1994). Size of the isolate was measured by micrometry and endospore staining was done by Dornor's method. Their colony characters taken in consideration were, colony size, shape, elevation, margins, opacity, pigmentation, reverse side pigment, pigment solubility, texture etc. The biochemical tests carried out for the isolate were: indole production test, methyl red test, Voges proskauer test, citrate utilization test, nitrate reduction test, ammonia production test, catalase test, urea utilization test, gelatin hydrolysis test, hydrolysis of starch, $\mathrm{H}_{2} \mathrm{~S}$ production test, dehydrogenase test. Growth pattern in broth, Carbohydrate utilization test etc. The classical method described in the identification key by Nonomura (1974) and Bergey's Manual of Determinative Bacteriology (Buchanan and Gibbons, 1974) was useful in the identification of Bacilli.

\section{Study of growth characteristics}

\section{Measure of growth curve of isolate B13}

$0.1 \mathrm{ml}$ culture was inoculated in nutrient broth, mixed well and immediately at $0 \mathrm{~h} \mathrm{O.D}$ was checked at $670 \mathrm{~nm}$. Then it was incubated at $37^{\circ} \mathrm{C}$ and at the interval of every $2 \mathrm{~h}$, O.D. was measured until the growth declined. The growth curve was plotted with optical density against time.

\section{Effect of pH on growth of isolate B13}

$0.1 \mathrm{ml}$ culture was inoculated in nutrient broth with different $\mathrm{pH}$ mixed well and immediately $0 \mathrm{~h}$ O.D checked at $670 \mathrm{~nm}$. Then 
it was incubated at $37^{\circ} \mathrm{C}$ and at the $24 \mathrm{~h}$, O.D. was measured until the growth.

\section{Effect of osmotic pressure on growth of B13}

$0.1 \mathrm{ml}$ culture was inoculated in nutrient broth with different salt concentration (gm\%), mixed well and immediately at 0 h O.D was checked at $670 \mathrm{~nm}$. Then it was incubated at $37^{\circ} \mathrm{C}$ and at the $24 \mathrm{~h}$, O.D. was measured.

Measure of alkaline protease production in routine medium and in medium with feathers as sole source of carbon and nitrogen

To compare the caseinolytic activity of enzyme produced by the isolates, the isolates were inoculated in production medium consisting of glucose $150 \mathrm{mg}, \mathrm{K}_{2} \mathrm{HPO}_{4} 20 \mathrm{mg}$, $\mathrm{KH}_{2} \mathrm{PO}_{4} 20 \mathrm{mg}, \mathrm{MgSO}_{4} 10 \mathrm{mg}, \mathrm{CaCl}_{2} 10 \mathrm{mg}$, casein $200 \mathrm{mg}, \mathrm{NaNO}_{3} 100 \mathrm{mg}, 100 \mathrm{ml}$ distilled water, pH-8.5 (Rao and Narasu, 2007) and put on an environmental shaker at $100 \mathrm{rpm}$ at $37^{\circ} \mathrm{C}$ for $72 \mathrm{~h}$ and checked for enzyme activity at interval of $24 \mathrm{~h}$.

The supernatant was collected after centrifugation at $10,000 \mathrm{rpm}$ for 15 minutes and used as crude enzyme source Keratinolytic activity in the supernatant was determined by using spectrophotometer method, given by Anson - Hagihara (1958) with minor modifications. Same exercise was repeated by inoculating the culture inoculums in the production medium containing feathers as sole source of carbon and nitrogen (Feathers $0.5 \mathrm{gm}, \mathrm{K}_{2} \mathrm{HPO}_{4} 20 \mathrm{mg}, \mathrm{KH}_{2} \mathrm{PO}_{4}$ $20 \mathrm{mg}, \mathrm{MgSO}_{4} 10 \mathrm{mg}, \mathrm{CaCl}_{2} 10 \mathrm{mg}, \mathrm{NaNO}_{3}$ $100 \mathrm{mg}, 100 \mathrm{ml}$ distilled water, $\mathrm{pH}-8.5$ ). Activity of enzyme was measured in terms of unit. $(\mu \mathrm{g} / \mathrm{ml} / \mathrm{min})$ One unit of enzyme is defined as the quantity of enzyme required to release $1 \mu \mathrm{g}$ of tyrosine per minute, under the standard assay conditions (Hameed et al., 1999).

\section{Optimization of production parameters}

\section{Incubation period}

B13 was inoculated in $250 \mathrm{ml}$ Erlenmeyer flasks containing $100 \mathrm{ml}$ of production medium, consisting of feathers as sole source of carbon and nitrogen and put on an environmental shaker at $100 \mathrm{rpm}$ at $37^{\circ} \mathrm{C}$ for $72 \mathrm{~h}$ and checked for enzyme activity at interval of 24h. The supernatant was collected after centrifugation at $10,000 \mathrm{rpm}$ for 15 minutes and used as crude enzyme source.

\section{Incubation temperature}

Effect of temperature on the production of extracellular protease production was analyzed by inoculating the isolate in various $250 \mathrm{ml}$ Erlenmeyer flasks containing $100 \mathrm{ml}$ of production medium and then incubated at different temperatures $\left(25,37,45^{\circ} \mathrm{C}\right)$ on environmental shaker at $100 \mathrm{rpm}$ for $48 \mathrm{~h}$. After incubation period, from each flask, protease production was analyzed for optimum temperature for maximum protease production by the isolate.

\section{Initial pH of the medium}

Effect of Initial $\mathrm{pH}$ of the production medium on production of extracellular protease was studied by assaying the enzyme after $48 \mathrm{~h}$ of incubation at $37^{\circ} \mathrm{C}$ by adjusting the initial $\mathrm{pH}$ of the production medium to different $\mathrm{pH}$ values ranging from 5.0 to 10 using appropriate buffers. Tris $\mathrm{HCl}$ buffer $(\mathrm{pH} 6.0$ 8.0), Glycine $\mathrm{NaOH}$ buffer (pH 8.0-11).

\section{Feather concentration (Substrate)}

The effect of Feather concentration on keratinolytic protease production by $B 13$ was carried out by inoculating $250 \mathrm{ml}$ Erlenmeyer flask containing $100 \mathrm{ml}$ of production medium with the different concentration of the feather $0.2 \%, 0.3 \% 0.4 \%, 0.5 \%, 0.6 \%$ and 
$1 \%$ gm $\%$ and incubating for $48 \mathrm{~h}$ at $37^{\circ} \mathrm{C}$, on an environmental shaker at $100 \mathrm{rpm}$. After incubation period, protease production was checked and results were analyzed for optimum substrate concentration for maximum protease production by the isolate.

\section{Inoculum size}

The effect of Inoculum size of the culture $B 13$ was carried out by inoculating $250 \mathrm{ml}$ Erlenmeyer flask containing $100 \mathrm{ml}$ of production medium with the different volumes of the inoculum $1.0 \mathrm{ml}, 2.0 \mathrm{ml}, 3.0$ $\mathrm{ml}, 4.0 \mathrm{ml}$ and $5.0 \mathrm{ml}$ (OD 0.75 at $670 \mathrm{~nm})$ of isolate for $48 \mathrm{~h}$ at $37^{\circ} \mathrm{C}$,on an environmental shaker at $100 \mathrm{pm}$. After incubation period, protease production was checked in terms of protease activity and results were analyzed for optimum inoculum size of the culture for maximum protease production by the isolate.

\section{Detergent compatibility and washing performance of keratinolytic alkaline protease}

The protease solution was pre incubated with different commercially available detergents like Tide, Rin, Arial and wheel etc (Kumar and Bhalla, 2004). Detergent solutions were prepared in $1 \mathrm{gm} \%$ and $0.3 \mathrm{ml}$ of detergent solution was mixed with $1.0 \mathrm{ml}$ of enzyme solution to make final concentration of detergent to $7.2 \mathrm{mg} / \mathrm{ml}$. the caseinolytic activity was determined at $37^{\circ} \mathrm{C}$ using Glycine $\mathrm{NaOH}$ buffer ( $\mathrm{pH} 9.0$ ) by Anson and Hagihara (1958) method. The relative activity was calculated with respect to the control without treatment, with any detergents.

Application of protease from isolate B13 as a detergent additive was studied by checking washing performance of protease on white cotton cloth pieces $(10 \mathrm{X} 10 \mathrm{~cm})$ stained with chocolate, as par (Adinarayana et al., 2003; Kumar and Bhalla, 2004). The following sets were prepared for the study.
(A)Trey with $100 \mathrm{ml} \mathrm{D/W}$ + cloth stained with chocolate.

(B)Trey with $100 \mathrm{ml} \mathrm{D} / \mathrm{W}$ + cloth stained with chocolate $+2 \mathrm{ml}$ crude enzyme.

(C)Trey with $100 \mathrm{ml} \mathrm{D} / \mathrm{W}+$ cloth stained with chocolate $+2 \mathrm{ml}$ crude enzyme $+2 \mathrm{ml} 1 \%$ detergent.

(D)Trey with $100 \mathrm{ml} \mathrm{D} / \mathrm{W}$ + cloth stained with chocolate $+2 \mathrm{ml} 1 \%$ detergent.

The trays were incubated at $37^{\circ} \mathrm{c}$ for $30 \mathrm{~min}$. After incubation, cloths pieces were taken out, rinsed with water and dried. Visual examination of various pieces exhibited the effect if enzyme in removal of stains.

\section{Results and Discussion}

\section{Screening of protease producing} microorganisms

Screening of alkaline protease producing bacteria from various sources was carried out using alkaline skim milk agar medium. Out of various isolates three most potent isolates were collected showing zone of casein hydrolysis surrounding their colonies. All were alkaliphilic and having diverse morphological characters. The figure 1 and table 1 is representing the growth of these isolates on skim milk agar plates.

All three isolates were studied for casein hydrolysis zone size, colony characteristics and morphological characters (Table 1).

\section{Comparative REA (relative enzyme activity) of isolates}

On the basis of morphology and cultural characteristics, it was confirmed that the isolates $\mathrm{A} 1$, and $\mathrm{M} 9$ were protease producing Actinomycetes and isolates B13 were Bacillus and all were producing good amount of alkaline protease on solid media. This was confirmed by performing REA (Figure 2 and 
3). Highest REA 3.57 was observed for Bacillus strain B13.Similar reports were made by Richa Jain (2009) for various Streptomyces species by the similar method (Figure 2).

\section{Selection of potent protease producing isolates}

Most of the isolates were having REA more than 2.0.So we counter checked them for their protease production capacity in production medium suggested by Rao and Narasu, 2007. When production profile of all the isolates was compared, Bacillus B13 was found producing maximum amount of protease within 48 h (140units/ml) (Figure 3). B13 produced highest keratinolytic protease among three isolates (117.5units/ml within 48h) using feathers as sole source of carbon and nitrogen. Though B13 produced protease using casein and glucose as carbon and nitrogen source (140.62 units/ml) higher than that of by using feathers as sole source of carbon and nitrogen (117.5 units/ml), as feathers are cheaper raw material, we selected feathers as substrate for enzyme production

\section{Identification of potent protease producing isolate $B 13$}

As we have decided to work with Bacillus, most explored bacteria for enzyme production. It was producing enzyme faster within $48 \mathrm{~h}$ in larger quantities using feathers only hence, we selected B13 for further studies. For its identification for we relied upon: Cultural and morphological characteristics, Biochemical characters and Growth parameter.

\section{Morphology, Cultural characteristics and Biochemical characteristics of B13}

The cultural characteristics, morphological characteristics and spore nature of the isolate B13 are presented in Table. 2 and photographs of the growth characteristics and gram staining are presented in figures $1,5 \mathrm{a}$ and $\mathrm{b}$. Results of biochemical tests carried out for isolate B13 are presented in Table:3.

\section{Growth parameters}

Various growth parameters of isolate were studied like, Growth curve, of isolate B13, effect of environmental $\mathrm{pH}$ and osmotic pressure on the growth. Growth curve (Figure 6 ) indicated that isolate grows best within $20 \mathrm{~h}$ and produces protease in its late stationary phase of life cycle and isolate B13 grows best at $\mathrm{pH} 11$ indicating that isolate is alkaliphilic (Figure 7). When effect of osmotic Pressure on growth of isolate B13 was studied, it was found that isolate B13 can grow in the range of $0.5 \mathrm{gm} \%$ to $6.5 \mathrm{gm} \%$ of $\mathrm{NaCl}$ (Figure 8 ).

\section{Protease production and optimization of certain parameters}

The protease production profile of B13 to determine incubation period of fermentation

The study of enzyme production is presented in figure 9. In which it was found that incubation period for best production was $48 \mathrm{~h}$ with maximum protease activity (117.5 units $/ \mathrm{ml})$. So throughout the study we considered $48 \mathrm{~h}$ as incubation period for the fermentation.

Similar kinds of results were also reported for B. subtilis AKRS3 Krishnan Ravishankar et $a l ., 2012$. Study of growth patterns indicated that maximum growth of isolate B13 (Figure: 9) was found at $20 \mathrm{~h}$ while the enzyme production was optimum at $48 \mathrm{~h}$ indicating that protease was produced maximally in late stationary phase of growth. Result was quite similar to that of reports for Streptomyces clavuligerus (Keila et al., 2001). 
Effect of temperature on protease production by isolate $B 13$

The growth and enzyme production are greatly influenced by incubation temperature. It was found that $37^{\circ} \mathrm{C}$ was the most favorable temperature for protease production by the isolate B13 (Figure 10). Similar reports were recorded for B.subtilis by Amira Hassan ALAbdalall and Eida marshid Al-khaldi (2016); and for B.cereus by Jeevana Lakshmi, kumari chitturi and lakshmi (2013).

\section{Effect of Initial pH of medium on protease production by isolate $B 13$}

Enzymes are normally active only within a certain $\mathrm{pH}$ interval and the total enzyme activity of the cell is therefore a complex function of the environmental $\mathrm{pH}$.

The results showed (Figure 11) that the enzyme production was maximum at $\mathrm{pH}$ 10.(106.5units $/ \mathrm{ml}$ ) Our result matches with the reports like, growth and protease production were maximum at $\mathrm{pH} 10$ for Bacillus clausii by Denizci et al., (2003) and Bacillus sp. JB 99 by Pushapalata Kainoor and Naik (2010)

\section{Determining optimum feather concentration of production medium for protease production by isolate $B 13$}

Optimum feather concentration of production medium for keratinolytic protease production by isolate B13 was found $0.5 \%$ (82.5units $/ \mathrm{ml})$. Similar results were noticed for organism Thermoactinomyeces sp. RM4 by Amit Verma et al., (2016).

Effect of inoculum size on protease production by isolate $B 13$

Inoculum size also affects the enzyme production greatly (Hameed et al., 1999).
Different inoculum sizes represented graphically (Figure 13) were investigated for their effect on productivity of the protease by B13.

The results indicated that the use of $2.0 \mathrm{ml}$ of $48 \mathrm{~h}$ old inoculum (optical density 0.75 at 660 $\mathrm{nm}$ ), gave the highest yield. Similar result was also found for Streptomyces pulvereceus MTCC 8374 by Jayasree et al., (2009). Our results are similar with organism Thermoactinomyeces sp. RM4 reported by Amit Verma et al., 2016 It is well documented that an inoculum size of $2 \%$ to $5 \%$ is optimum for protease production (Mabrouk et al., 1999; Kanekar et al., 2002).Moreover, in the reports of Sinha and Satyanarayana (1991) and according to Gajju et al., (1996) range of $1 \%$ to $8 \%$ inoculums was the optimum.

\section{Detergent compatibility test}

Our crude protease (117.5 units/ml) exhibited significant compatibility with commercial laundry detergents like Wheel, Rin and Tide. The enzyme retained $99.46 \%$ of its original activity after incubating the enzyme at $37 \mathrm{C}$ for $30 \mathrm{~min}$ before the enzyme assay in the presence of wheel and $87.23 \%$ activity in presence of Arial.

Protease exhibited stability in the following order wheel > Tide > Rin > Arial. Alkaline protease of B13 had shown high compatibility with most of the commercially available detergents like wheel, Tide and Rin hence, can be used efficiently as detergent additive (Figure 14).

Protease from Bacillus strain B13 was also reported for removal of chocolate stain and compatibility with commercial detergent. The basic requirements for proteases for their detergent application include (Gupta and Beg, 2002): 
i. Availability at low cost from safe microbial source

ii. Capable of working in high alkaline $\mathrm{pH}$ of common detergent solution
iii.Sufficiently thermostable with higher temperature optimum

iv. Low or no allergic response for topical use

v. Compatibility with detergent component

Table.1 Cultural and morphological characters of keratinolytic protease producing isolates

\begin{tabular}{|l|l|l|l|}
\hline Isolates & Sample source & Colony characters & Gram reaction \\
\hline A1 & $\begin{array}{l}\text { Rock sample, Dalhousie, } \\
\text { Himachal Pradesh }\end{array}$ & $\begin{array}{l}\text { Small, round, even, slightly } \\
\text { raised, opaque, rough, white, } \\
\text { grey pigment on aging }\end{array}$ & $\begin{array}{l}\text { Gram +ve spore forming } \\
\text { filamentous }\end{array}$ \\
\hline B13 & $\begin{array}{l}\text { Soil sample of Manikarnam near } \\
\text { Manali, Himachal Pradesh }\end{array}$ & $\begin{array}{l}\text { Small, round, uneven, raised, } \\
\text { smooth, opaque with red pigment } \\
\text { after 48h }\end{array}$ & $\begin{array}{l}\text { Gram+ve rod single and in } \\
\text { pairs, spore forming }\end{array}$ \\
\hline M9 & $\begin{array}{l}\text { Soil sample of Manikarnam near } \\
\text { Manali, Himachal Pradesh }\end{array}$ & $\begin{array}{l}\text { Small, round, uneven, slightly } \\
\text { raised, rough, opaque, light white }\end{array}$ & Gram+ve filamantous \\
\hline
\end{tabular}

Table.2 Cultural and morphological characteristics of Bacillus sp B13

\begin{tabular}{|l|l|l|l|l|l|l|l|l|}
\hline Isolate & Size & Shape & Margin & Texture & Elevation & Opacity & $\begin{array}{l}\text { Colony } \\
\text { Color }\end{array}$ & $\begin{array}{l}\text { Morphology by Gram } \\
\text { staining }\end{array}$ \\
\hline B13 & Small & Round & Uneven & Smooth & $\begin{array}{l}\text { Slightly } \\
\text { raised }\end{array}$ & Opaque & Red & $\begin{array}{l}\text { Gram positive, rod } \\
\text { shaped, arranged in pairs } \\
\text { and in clusters with } \\
\text { spore formation }\end{array}$ \\
\hline
\end{tabular}

Table.3 Biochemical Activity of isolate B13

\begin{tabular}{|l|l|l|}
\hline No. & Test $\backslash$ Org. & B13 \\
\hline 1 & M.R. test & Positive \\
\hline 2 & V.P. test & Negative \\
\hline 3 & Nitrate reduction test & Positive \\
\hline 4 & Gelatin hydrolysis test & Positive \\
\hline 5 & Catalse test & Negative \\
\hline 6 & Indole production test & Negative \\
\hline 7 & Growth of 6.5\% NaCL & Positive \\
\hline 8 & H2S production test & Negative \\
\hline 9 & Citrate utilization test & Positive \\
\hline 10 & Urea utilization (Urease activity) & Negative \\
\hline 11 & Carbohydrate utilization test & Negative \\
& $\begin{aligned} \text { P) Glucose } \\
\text { Positive } \\
\text { Positive } \\
\text { Positive }\end{aligned}$ \\
\hline 12 & 3) Xylose & uniform growth \\
\hline 13 & Amylase Production test/ starch hydrolysis & Positive \\
\hline
\end{tabular}


Fig.1 Skim milk agar medium showing colonies of protease producers

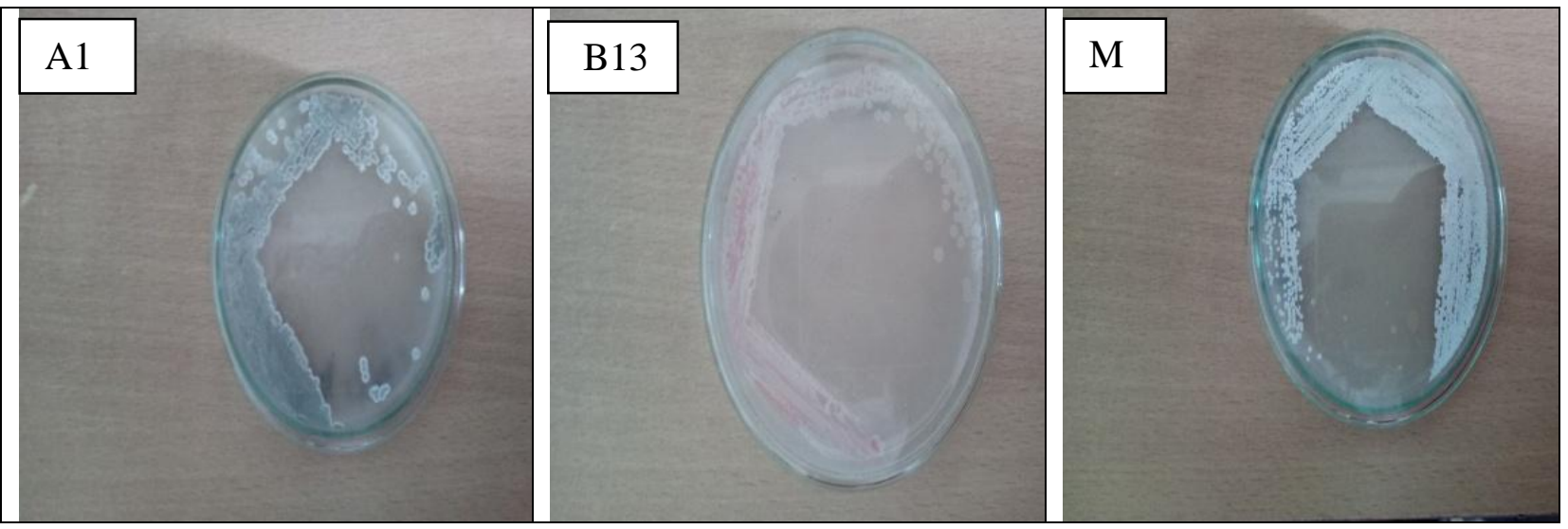

Fig.2 Relative activities of isolates

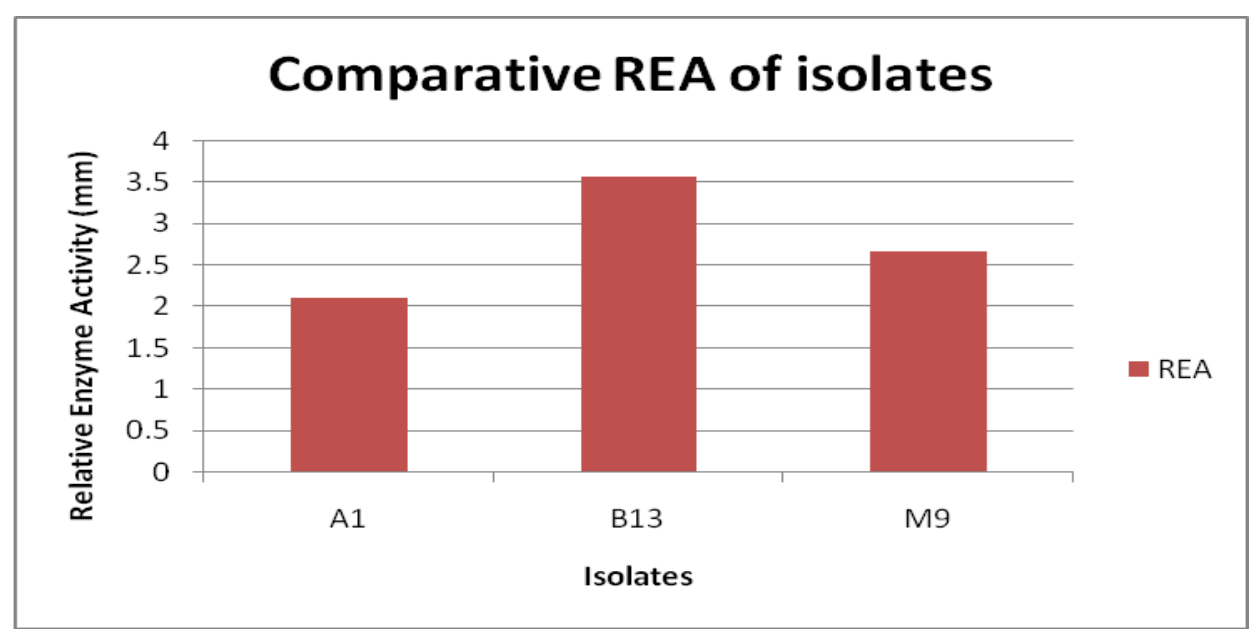

Fig.3 Alkaline protease production profile by isolates using medium suggested by Rao and Narasu (Glucose and casein as substrate)

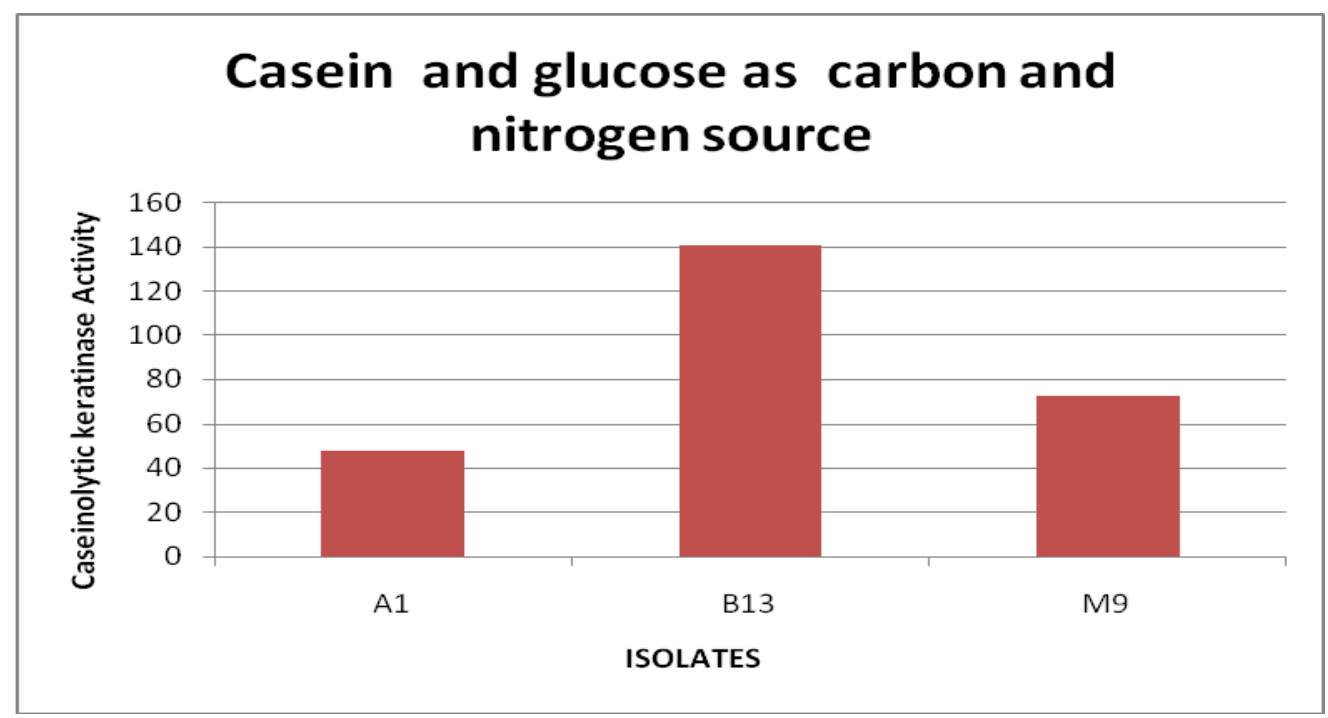


Fig.4 Alkaline protease production by isolates using feathers as sole source of carbon and nitrogen

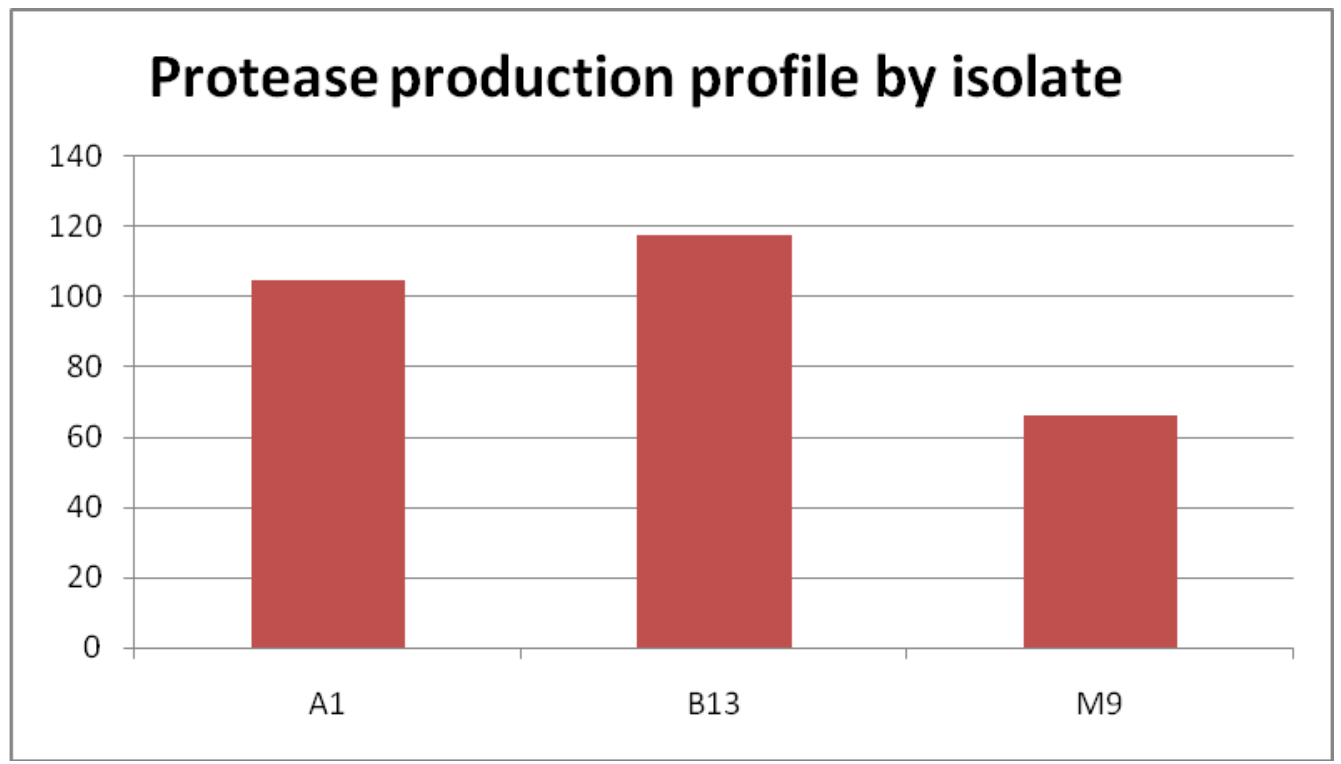

Fig.5a. Morphology by Gram's staining of isolate B13; b. Micrometery for measuring size of isolate B13. Length $(4 \mu \mathrm{m})$ and width $(1 \mu \mathrm{m})$; c Spore staining performed by Dorner's method. Showing centrally located endospores
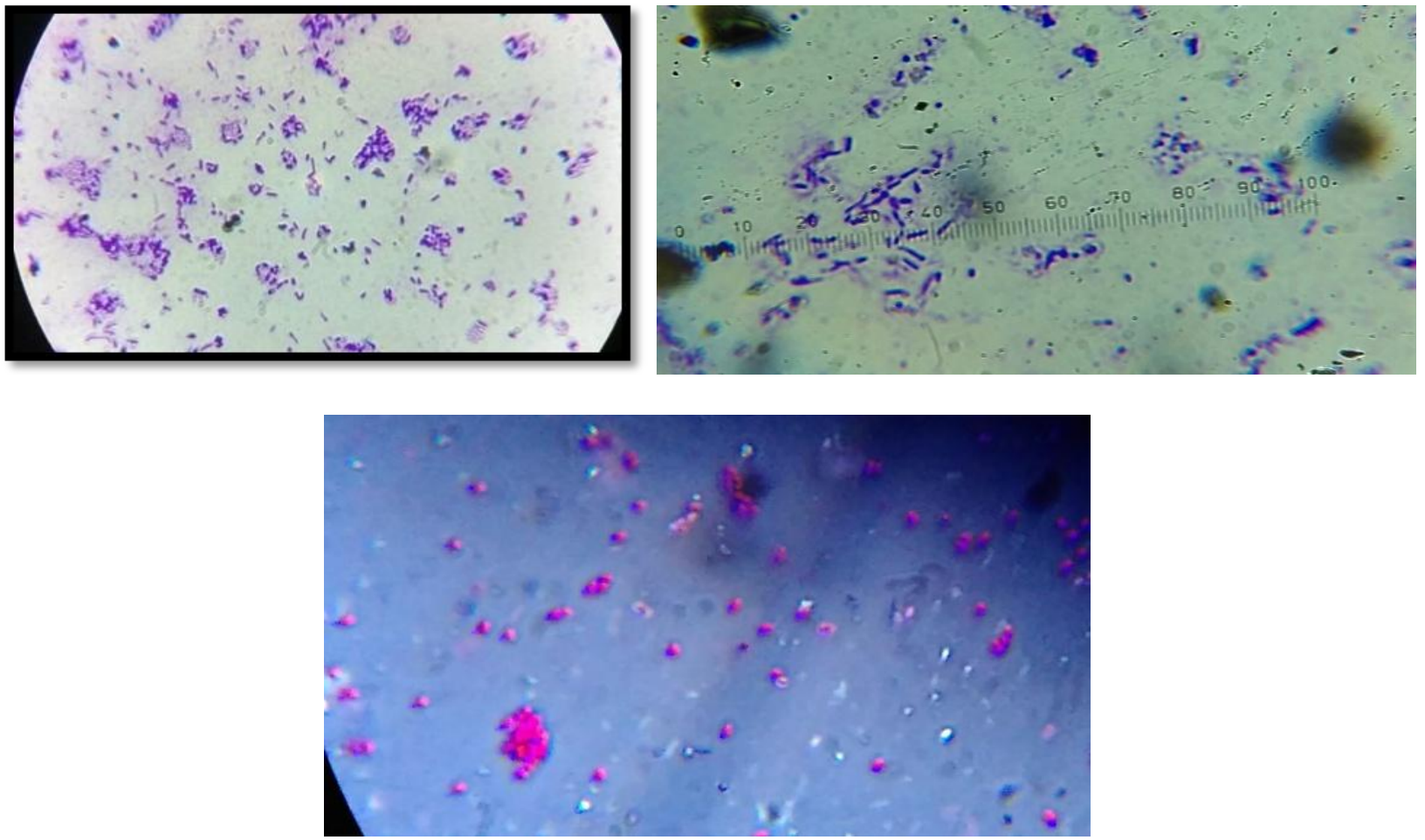
Fig.6 Growth curve of isolate B13

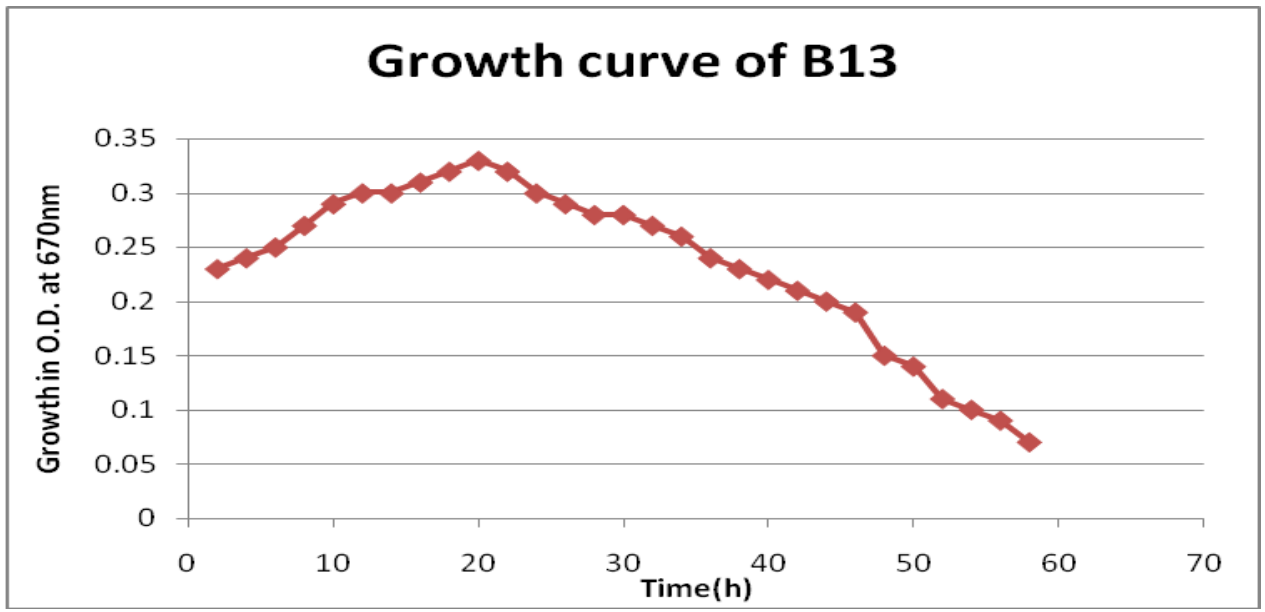

Fig.7 pH on growth by isolate B13 in nutriebt broth

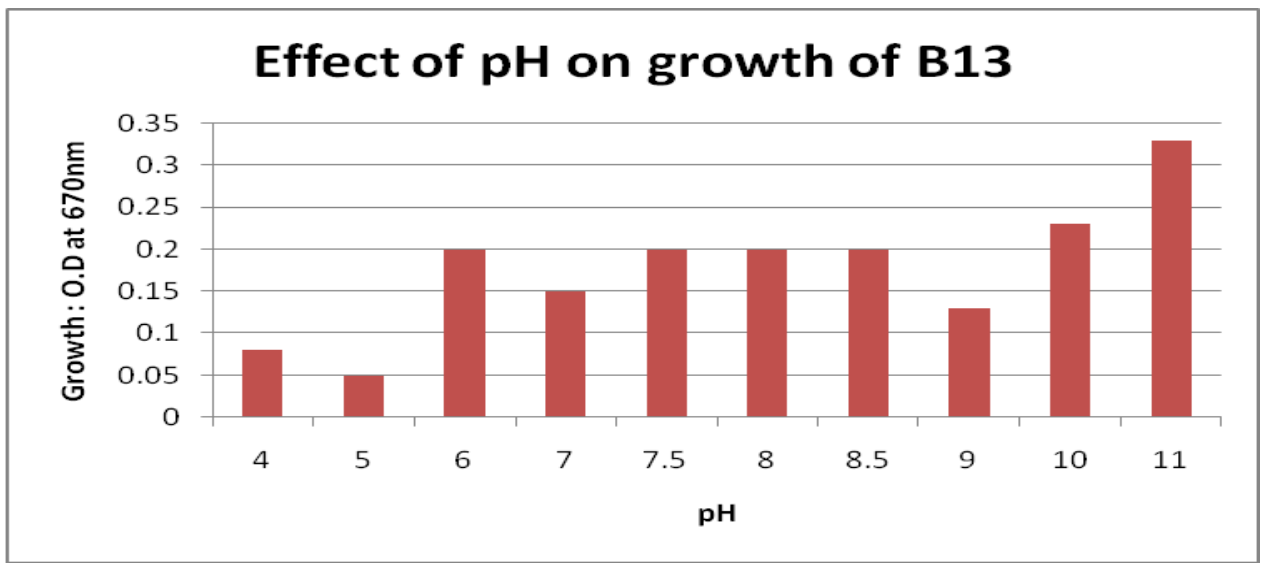

Fig.8 Effect of osmotic pressure on growth of isolate B13

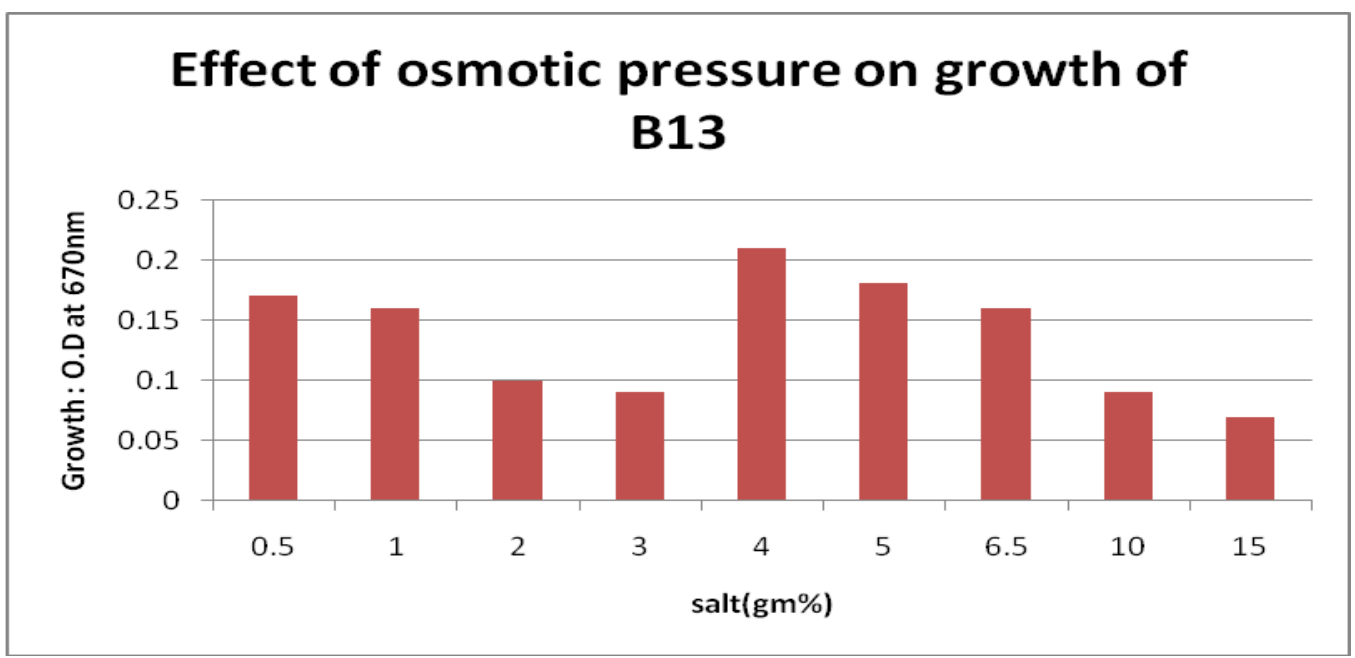


Fig.9 The protease production profile of B13 to determine incubation period with reference to growth

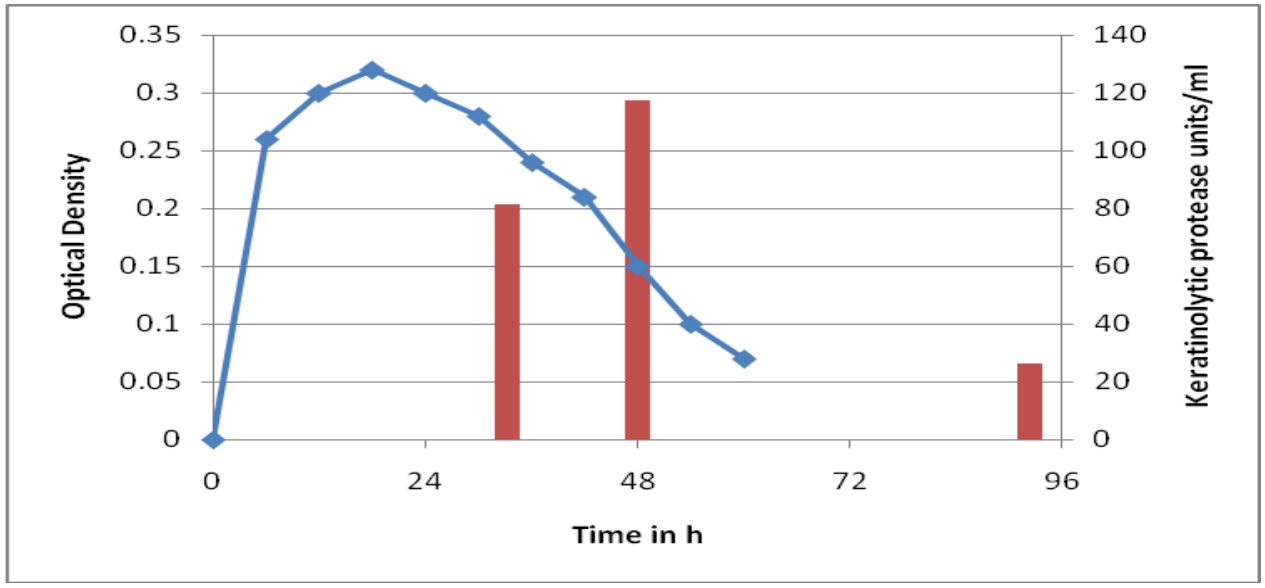

Fig.10 Effect of temperature on protease production by isolate B13

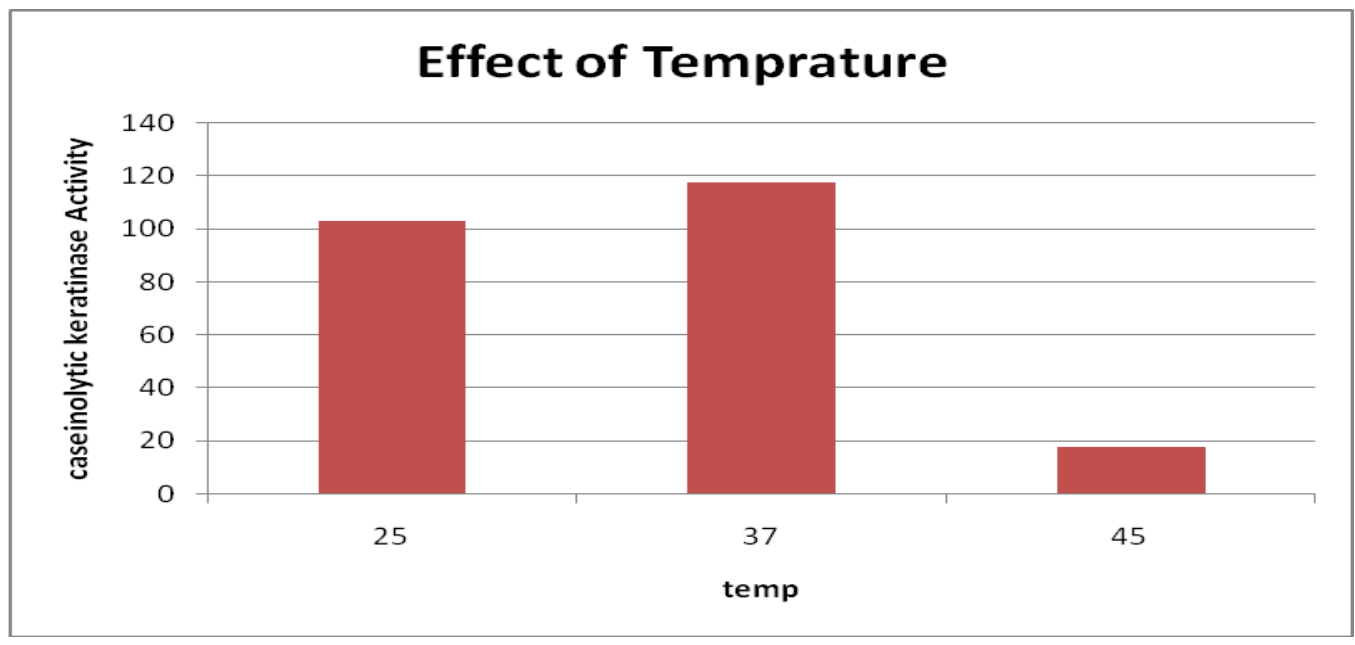

Fig.11 Effect of medium $\mathrm{pH}$ on protease production

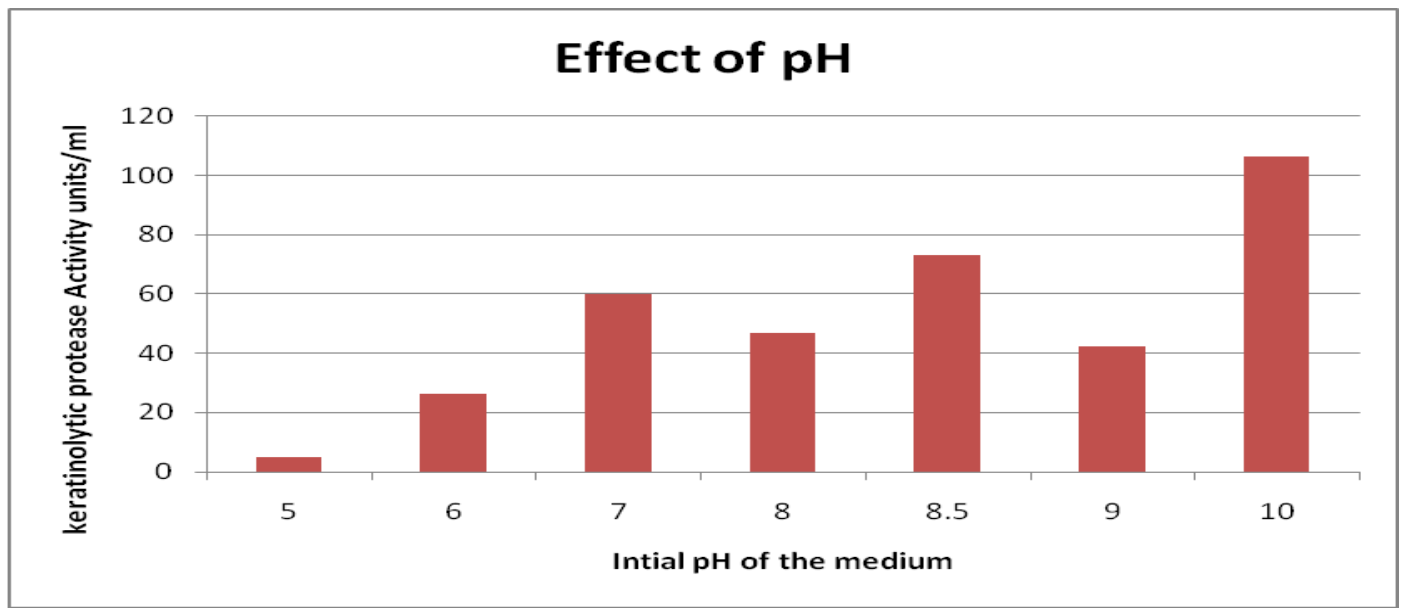


Fig.12 Effect of feather concentration on protease production by B13.

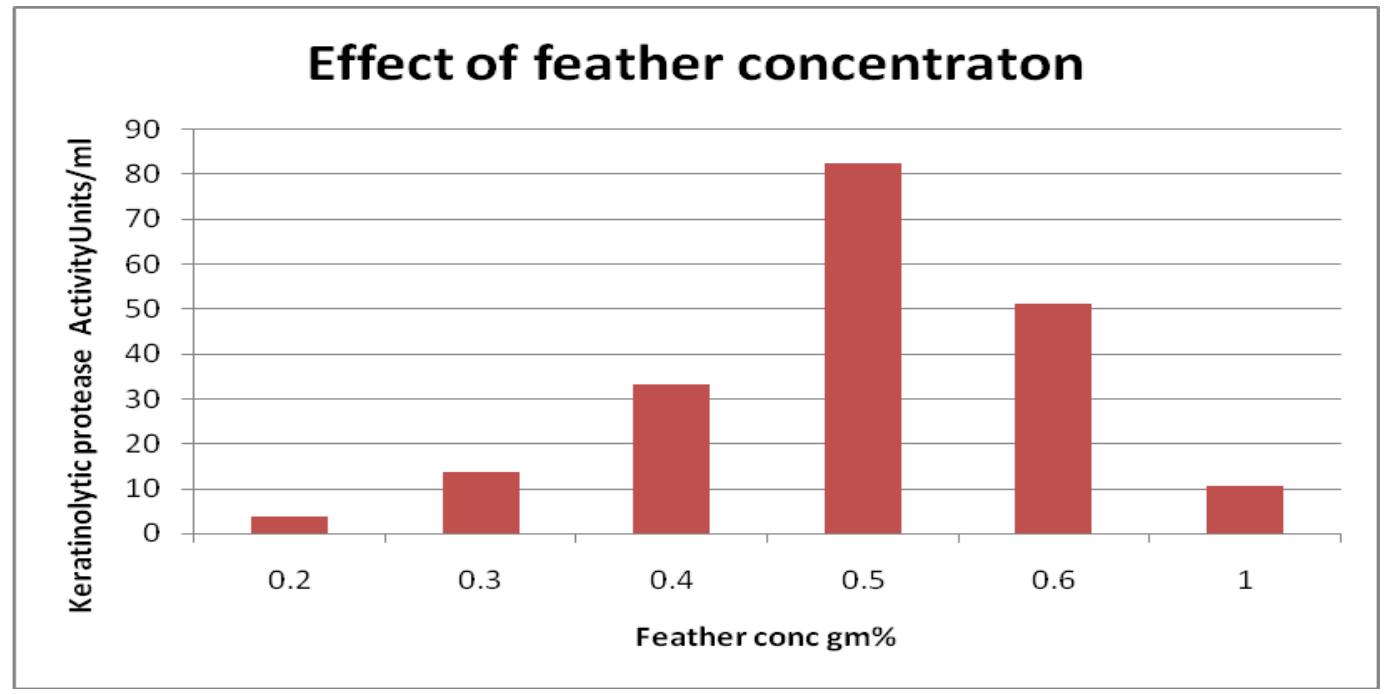

Fig.13 Effect of inoculum volume on protease production by B13

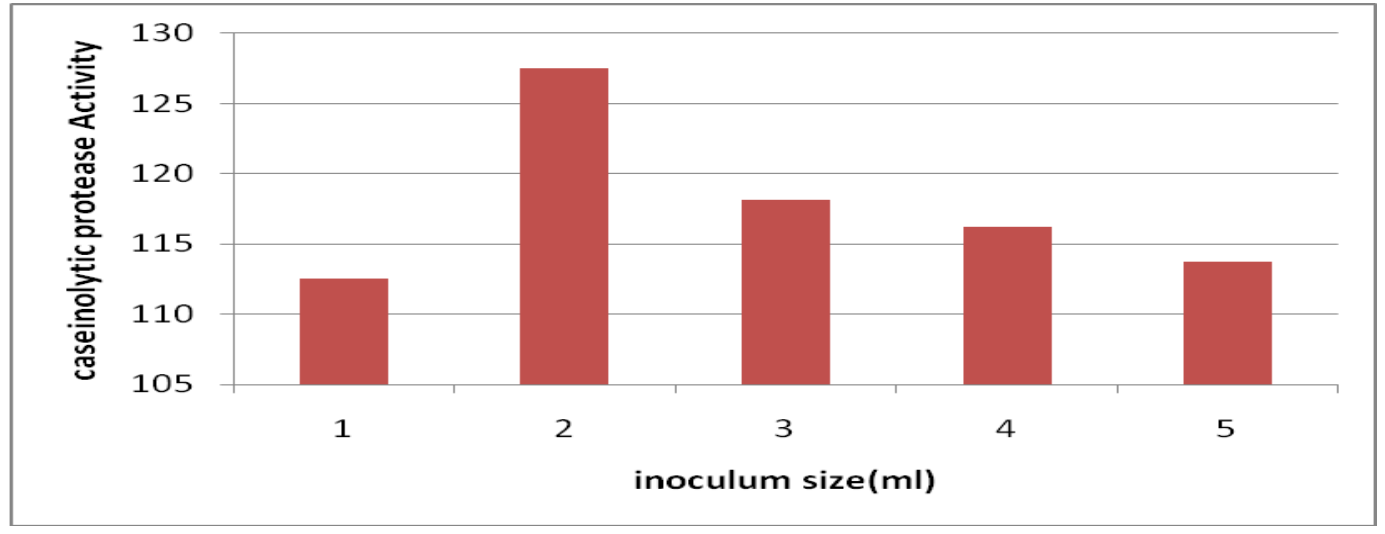

Fig.14 Compatibility of protease of B13 with commercial detergents

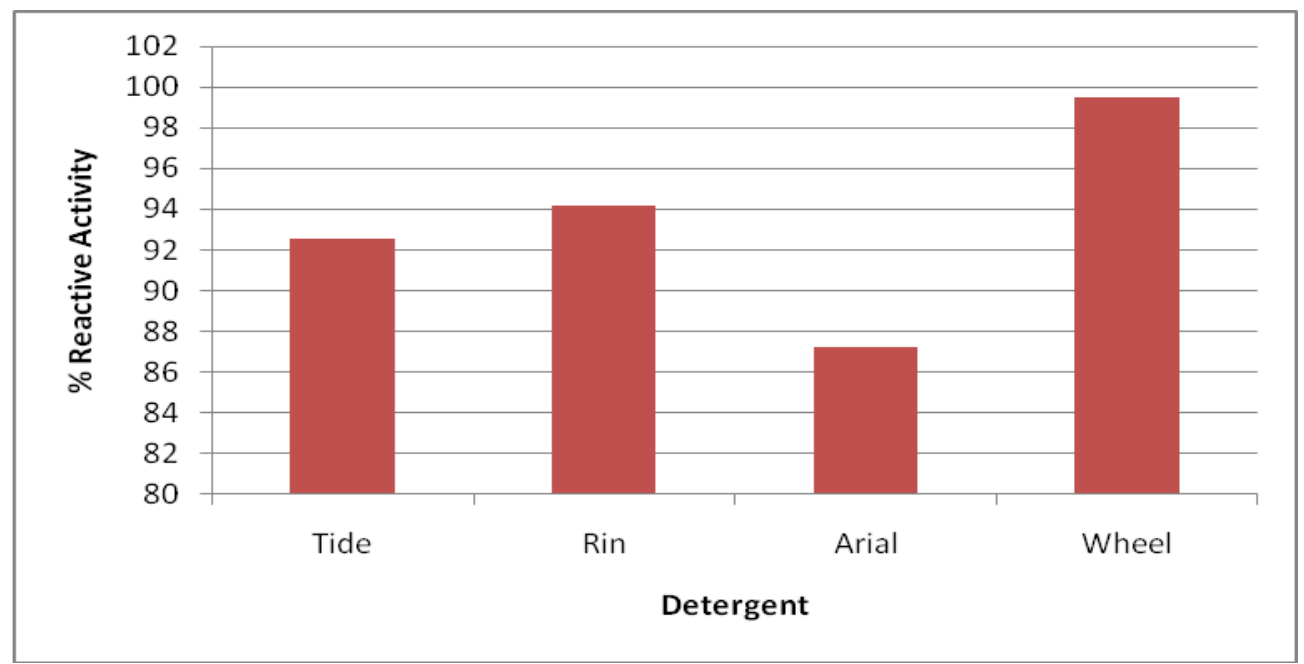


Fig.15 Washing performance of protease of A1 (A: only water wash, B: only enzyme, C: detergent and enzyme, D:only detergent)

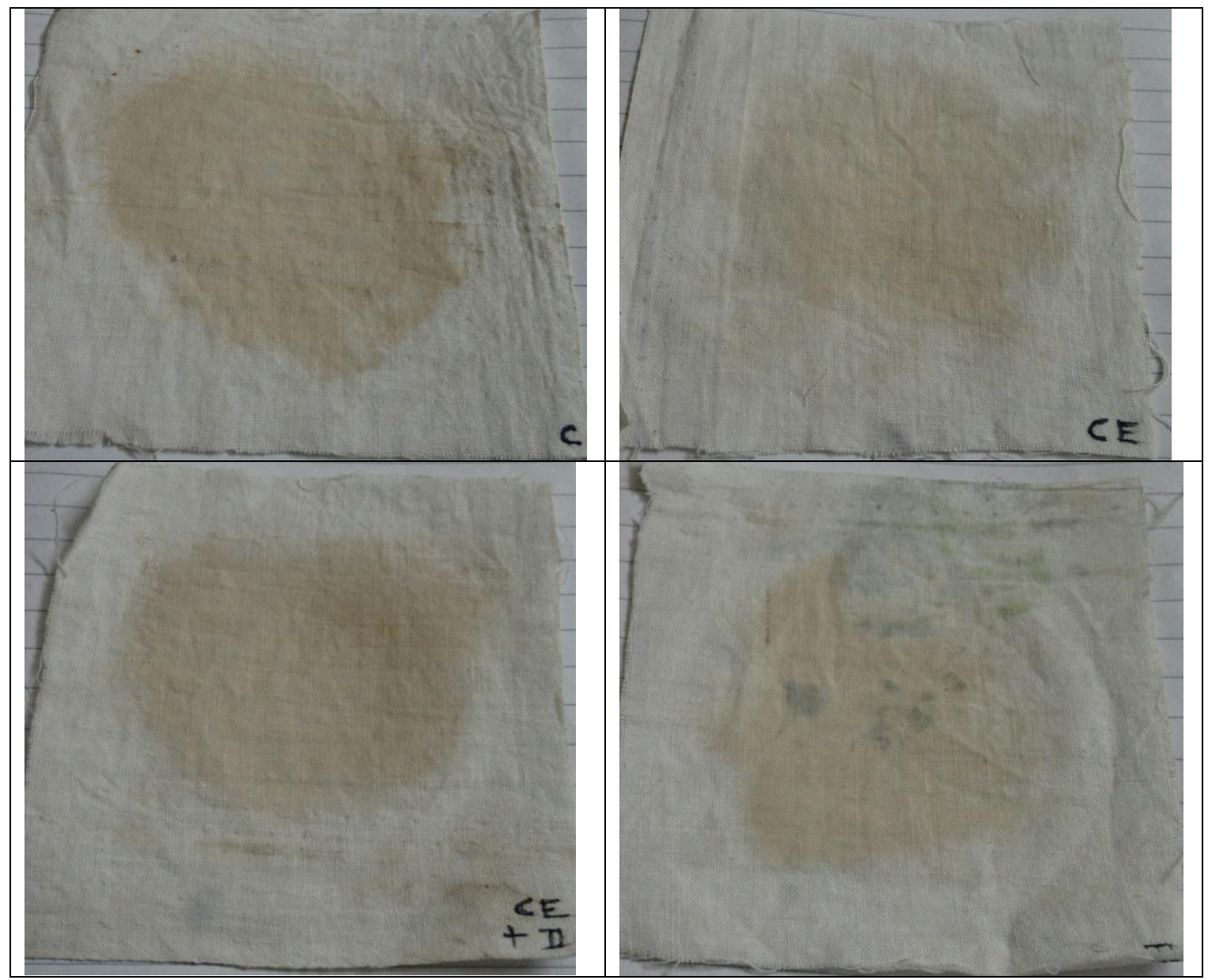

Washing performance of protease of B13 was studied on white cotton cloth pieces $(10 \times 10)$ stained with chocolate

After $30 \mathrm{~min}$ of incubation at room temperature the detergent solution supplemented with the enzyme was able to remove the chocolate stains completely, while the detergent solution only could not remove it. The best washing performance was recorded by washing with only enzyme, followed by washing with detergent, washing with enzyme+detergent and washing with only water. Bhosale et al., (1995) have reported high activity of alkaline protease of Conidiobolus coronatus showing compatibility at $37 \mathrm{C}$ in the presence of 25 $\mathrm{mM} \mathrm{CaCl} 2$ with varieties of detergents.
Adinarayana et al., (2003) worked with Bacillus subtilis PE II proteases and reported its compatibility and stability with various locally available detergents at $37 \mathrm{C}$. same kinds of studies were also reported for proteases from Siplosoma obliqua (Anwar and Saleemuddin, 1997), Bacillus brevis (Banerjee et al., 1999), Bacillus cereus (Kanmani et al., 2011).

\section{Acknowledgements}

We are thankful to UGC, India for providing financial support to carry out the project work in the form of minor research project. We are also thankful to $\mathrm{J}$ and $\mathrm{J}$. College of science, Nadiad for providing laboratory facility to carry out this work. 


\section{References}

Adinarayana, K., Ellaiah, P. and Prasad, D.S. 2003. Purification and Partial Characterization of Thermostable Serine Alkaline Protease from a Newly Isolated Bacillus subtilis PE-11. AAPS Pharm. Sci. Tech., 4: article, 56.

Amira Hassan AL-Abdalall and Eida marshid Al-khaldi. 2016. "Production of alkaline proteases by alkalophilic Bacillus subtilis during recycling animal and plant wastes" Vol. 15(47), pp. 26982702.

Amit Verma, Hukum Singh, Mohammad S. Anwar, Shailendra Kumar, Mohammad W. Ansari, and Sanjeev Agrawa. 2016. "Production of Thermostable Organic Solvent Tolerant Keratinolytic Protease from Thermoactinomyces sp. RM4: IAA Production and Plant Growth Promotion." Front Microbiol., 7: 1189.

Anwar, A. and Saleemuddin, M. 1997. Alkaline-pH-acting digestive enzymes of the polyphagous insect pest Spilosoma obliqua: stability and potential as detergent additives. Biotechnol. App. Biochem., 25: 43-46.

Banerjee, U.C., Sani, R.K., Azmi, W., Soni, R. 1999. Thermostble alkaline protease from Bacillus brevis and its characterization as laundry detergent additive. Process Biochem., 35: 213219.

Bergey, D.H., John, G.H., Noel, R.K., Peter

H.A. 1994. Bergey's Manual of Determinative Bacteriology (9th ed), Lippincott Williams and Wilkins.

Bhosale, S.H., Rao, M.B., Deshpande, V.V., Srinivasan, M.C. 1995. Thermostability of high-activity alkaline protease from Conidiobolus coronatus (NCL 86.8.20). Enzyme Microb. Technol., 17: 136-139. Buchanan, R.E. and Gibbons, N.E., eds. 1974. Bergey's Manual of Determinative Bacteriology. 8th ed. Williams and
Wilkins Co., Baltimore, Md. 21202. xxvi + 1246

Denizci, A.A., D. Kazan, E.C.A. Abeln and A. Erarslan. 2004. Newly isolated Bacillus clausii GMBAE 42: an alkaline protease producer capable to grow under higly alkaline conditions." $J$ Appl. Microbiol., $\quad$ 96: $320-327$ doi:10.1046/j.1365-2672.2003.02153.x

Gajju, H., Bhalla, T.C., Agarwal, H.O. 1996. Thermostable alkaline protease from thermophilic Bacillus coagulans PB-77. Indian J. Microbiol., 36: 153-155.

Gupta, R., Beg Q.K., Loranz P. $2002 \mathrm{a}$. Bacterial alkaline proteases: molecular approaches and industrial applications. Appl. Microbiol. Biotechnol., 59(1): 1532.

Hagihara, B. 1958. The enzymes. Volume 4, Academic press Inc, New York.

Hameed, A., Keshavarz, T., Evans, C.S. 1999. Effect of dissolved oxygen tension and $\mathrm{pH}$ on the production of extracellular protease from a new isolate of Bacillus subtilis K2, for use in leather processing. J. Chem. Technol. Biotechnol., 74: 5-8.

Jain Richa, S.C., Agrawal and P.C. Jain. 2008. Proteolytic Actinomycetes from Indian Habitats, J. Culture Collections, vol: 6 .

Jain, R., Agrawal, S.C., and Jain, P.C. 2009. Proteolytic Actinomycetes from Indian Habitats. J. Culture Collections, 6: 2837.

Jayasree, D., T.D. Sandhya Kumari, P.B. KaviKishor, M. Vijaya Lakshmi, M. Lakshmi Narasu, Optimization of Production Protocol of Alkaline Protease by Streptomyces pulvereceus. Inter JRI Sci.Technol., Vol. 1, Issue 2, 79-82.

Jeevana Lakshmi, P., ch.M. Kumari chitturi and V.V. Lakshmi. 2013. Efficient Degradation of Feather by Keratinase Producing Bacillus sp. Int. J. 
Microbiol., $\quad$ Volume 2013, http://dx.doi.org/10.1155/2013/608321

Kanekar, P.P., Nilegaonkar, S.S., Sarnaik, S.S., Kelkar, A.S. 2002. Optimization of protease activity of alkaliphilic bacteria isolated from an alkaline lake in India. Bioresour Technol; 85: 87-93.

Kanmani, R., Dhivya, S., Jayalakshmi, S. and Vijayabaskar, P. 2011. Studies on detergent additives of protease enzyme from an estuarine bacterium Bacillus cereus. Int. Res. J. Biotechnol., 2: 157163.

Keila Aparecida Moreira; Maria Taciana Holanda Cavalcanti, Helena Simões Duarte; Elias Basile Tambourgi, Eduardo Henrique Magalhães de Melo, Valdinete Lins Silva, Ana Lúcia Figueiredo Porto, José Luiz de Lima Filho' 2001. "Partial Characterization Of Proteases From Streptomyces Clavuligerus Using An Inexpensive Medium" Braz. J. Microbiol., vol.32 no.3 SãoPaulo Aug./ Oct. 2001.

Krishnan Ravishankar, P., Santhosh Kumar,
Biju Jacob, K. Saravanan, Muthusamy Ashok Kumar, Anu Jacob. 2012. Optimal conditions for production of extracellular alkaline protease from a newly isolated Bacillus subtilis strain AKRS3, Res. Biotechnol., 3(5): 45-54.

Kumar, D. and T.C. Bhalla. 2004. Purification and characterization of a small size protease from Bacillus sp. APR-4. Indian J. Exp. Biol., 42: 515-521.

Lowry, O.H., Rosebrough, N.J., Farr, A.l., Randall, R. 1951. Protein measurement with the Folin phenol reagent. J. Biol. Chem., 193(1): 265-75.

Mabrouk, S.S., Hashem, A.M., Wl-Shayeb, N.M.A., Ismail, A.M.S., Addel-fattah, A.F. 1999. Optimization of alkaline protease productivity by Bacillus licheniformis ATCC 21415. Bioresour. Technol., 69: 155-159.

Pushapalata, L., S. Kainoor and G.R. Naik. 2010. "Production and characterization of feather degrading keratinase from Bacillus sp. JB 99" Indian J. Biotechnol., 9(4): 384-390.

\section{How to cite this article:}

Shilpa Ashok Jani, Sumaiya Malek, Anvi Patel, Krupa Pathak and Kinjal Baria. 2017. Production of Alkaline Keratinolytic Protease by Bacillus sp. B13 from Feather Waste. Int.J.Curr.Microbiol.App.Sci. 6(5): 1538-1552. doi: https://doi.org/10.20546/ijcmas.2017.605.168 